\title{
ASSESSING THE IMPACT OF DESIGN FACTORS ON THE PERFORMANCE OF TWO MINIATURE MICROBIAL FUEL CELLS
}

Sara Mateo ${ }^{1,2}$, Michele Mascia ${ }^{3}$, Francisco Jesus Fernandez-Morales ${ }^{2}$, Manuel Andrés Rodrigo $^{2}$, Mirella Di Lorenzo ${ }^{1 *}$

${ }^{1}$ Centre for Biosensors, Bioelectronics and Biodevices and Department of Chemical Engineering, University of Bath, Bath, BA2 7AY, United Kingdom.

2 ITQUIMA, Chemical Engineering Department, University of Castilla-La Mancha, 13071 Ciudad Real, Spain.

${ }^{3}$ Dipartimento di Ingegneria Meccanica, Chimica e dei Materiali, Universitá degli Studi di Cagliari, Cagliari, Italy

*corresponding author: m.di.lorenzo@bath.ac.uk 


\begin{abstract}
Every day, wastewater treatment requires large amounts of electricity. Microbial Fuel Cells (MFCs) can convert wastewater treatment plants from net power consumers into energy neutral/positive systems by generating electricity from wastewaters. We investigate here the design factors that have major impacts on the performance of two miniature MFCs, and, consequently, of the resulting stack of MFCs. A versatile mathematical model is provided, which simulates the complex MFC system by integrating fluid dynamic principles with mass transport phenomena and (bio)electrochemical reactions. The model is used to support an in-depth study of the two MFCs, which differ for electrode spacing, anodic volume and fluid pattern within the anodic chamber, and to associate any difference in performance to design factors. Finally, system scale-up is demonstrated by generating stacks of the two MFCs. Thanks to the versatility of the model developed, this study becomes a guide for the effective development of future miniature MFCs.
\end{abstract}

\title{
Keywords
}

Miniature microbial fuel cell; cascade of microbial fuel cells; wastewater treatment; bioelectricity 


\section{List of symbols}

\begin{tabular}{|c|c|c|}
\hline Symbol & Description & [unit] \\
\hline$a_{F}$ & Specific area of carbon felt & $17,700\left[\mathrm{~m}^{-1}\right]$ \\
\hline$c_{i}$ & Concentration of the $i^{\text {th }}$ specie & {$[\mathrm{mM}]$} \\
\hline$D_{i}$ & Diffusivity coefficient of the $\mathrm{i}^{\text {th }}$ compound & {$\left[\mathrm{m}^{2} \mathrm{~s}^{-1}\right]$} \\
\hline$d_{N}$ & Inlet nozzle diameter & {$[\mathrm{mm}]$} \\
\hline$E$ & Electric Potential & {$[\mathrm{V}]$} \\
\hline $\mathrm{F}$ & Faraday constant & $96,500\left[\mathrm{C} \mathrm{mol}^{-1}\right]$ \\
\hline 1 & Current Intensity & {$[\mathrm{A}]$} \\
\hline j & Anodic/Cathodic current density & {$\left[\mathrm{A} \mathrm{m} \mathrm{m}^{-2}\right]$} \\
\hline$k_{A C}$ & equilibrium constant for acetic acid dissociation & $1.8 \times 10^{-5}$ \\
\hline $\mathrm{k}_{\mathrm{HF}}$ & Hydraulic conductivity of carbon felt & $1 \times 10^{-10}\left[\mathrm{~m}^{2}\right]$ \\
\hline $\mathrm{k}_{\mathrm{I}}$ & Inhibition constant & {$\left[\mathrm{g}_{\mathrm{O} 2} \mathrm{dm}^{-3}\right]$} \\
\hline $\mathrm{k}_{\mathrm{s}}$ & Half-saturation constant & {$\left[\mathrm{g}_{\mathrm{O} 2} \mathrm{dm}^{-3}\right]$ or $[\mathrm{mM}]$} \\
\hline$k_{w}$ & equilibrium constant for the self-ionization of water & $1 \times 10^{-14}$ \\
\hline $\mathrm{P}$ & Power & {$[\mathrm{W}]$} \\
\hline$q_{\text {in }}$ & Inlet flow rate & {$\left[\mathrm{cm}^{3} \mathrm{~s}^{-1}\right]$} \\
\hline $\mathrm{R}$ & Ideal gas constant & $8.3\left[\mathrm{~J} \mathrm{~K}^{-1} \mathrm{~mol}^{-1}\right]$ \\
\hline$r_{i}$ & specific reaction rate of the $i^{\text {th }}$ compound & {$\left[\mathrm{mol} \mathrm{m}^{-3} \mathrm{~s}^{-1}\right]$} \\
\hline $\mathrm{T}$ & Operating temperature & $298[\mathrm{~K}]$ \\
\hline$v$ & Anolyte velocity & {$\left[\mathrm{m} \mathrm{s}^{-1}\right]$} \\
\hline z & Number of electrons involved in the electrochemical reaction & 8 \\
\hline$\rho_{w}$ & Density of water & $1,000\left[\mathrm{~kg} \mathrm{~m}^{-3}\right]$ \\
\hline$\delta_{M}$ & Membrane thickness & $200[\mu \mathrm{m}]$ \\
\hline$\varepsilon_{C P}$ & Porosity of GDE & 0.4 \\
\hline$\varepsilon_{\mathrm{F}}$ & Porosity of carbon felt & 0.94 \\
\hline$\mu$ & Specific growth rate & {$\left[\mathrm{d}^{-1}\right]$} \\
\hline$\mu_{\mathrm{w}}$ & Viscosity of water & $1[\mathrm{cP}]$ \\
\hline$\eta_{F}$ & Faradaic yield & \\
\hline$\sigma$ & Electrical Conductivity & {$\left[\mathrm{S} \mathrm{m}^{-1}\right]$} \\
\hline$\tau_{F}$ & Tortuosity of carbon felt & 2 \\
\hline
\end{tabular}

\section{Subscripts}

$\begin{array}{ll}\text { A } & \text { Anodic } \\ \mathrm{C} & \text { Cathodic } \\ \mathrm{H}^{+} & \text {Protons } \\ \mathrm{Ac} & \text { Acetate }\end{array}$




\section{Introduction}

A billion litres of sewage are produced every day in Europe (CimochowiczRybicka). To meet stringent targets on effluent water quality, Wastewater Treatment Plants (WWTPs) require up to $5 \%$ of the average daily electricity consumption for sewage treatment. Most of this energy is currently originated from fossil fuels. Consequently, WWTPs heavily contribute to greenhouse gas emissions and to the associated environmental issues, such as global warming and climate change (Ashrafi et al., 2014). A transformative approach would be to convert WWTPs from net power consumers into energy neutral or even energy positive service providers. This approach can be possible by properly exploiting the chemical energy of organic compounds in wastewater. In this way, WWTPs would help address the EU commitment to reach a $40 \%$ greenhouse gas emission reduction by 2030. Along with anaerobic digesters, microbial fuel cells (MFCs) can be an interesting option. An MFC is a unique carbon-neutral technology that is capable to treat wastewater while generating useful electricity. This feature has attracted many researchers, as demonstrated by the considerable number of studies reported during the last decades and summarised in a recent review (Santoro et al., 2017). MFCs rely on so-called electroactive microorganisms that can transfer the electrons generated during the oxidation of organic compounds to an external electrode (the anode).

Research into MFCs has been focused mainly on the anodic biofilm (Fernández de Dios et al., 2013; Li et al., 2018), the electrode and membrane material (Santoro et al., 2017), the type of feedstock and the oxidation reduction reaction catalyst at the cathode (Rahimnejad et al., 2015). The fuel cell design and scale-up strategy represent two other key aspects that should be further investigated.

With respect to the design, a growing attention is dedicated to small-scale devices, due to easy fabrication and the possibility to precisely manipulate the fluid dynamic conditions. Miniaturised MFcs with three dimensional electrodes shows high electrode surface area to volume ratio, that enhances the mass transfer processes and the reaction rates (Ringeisen et al., 2005; Ringeisen et al., 2006; Yang et al., 2016).

On the other hand, it has been proven that the most viable way for scaling-up the technology is to arrange multiple MFC units in stacks (Ieropoulos et al., 2013). As such,

miniature MFC designs are particularly attractive because they can facilitate the 
development of compact stacks of multiple units, at a reasonably contained overall volume (Chouler et al., 2016; Ieropoulos et al., 2013; Walter et al., 2016b).

With respect to the scale-up strategy, both the series and parallel configurations have been tested for the electrical connection of the MFC units in stacks. An electrical connection in series leads to an overall voltage equal to the sum of the individual voltages of the units connected, with no change in the current generated by the single MFC units. This connection strategy, however, can produce a voltage reversal phenomenon that can damage MFC units in the stack (An et al., 2016; Ortega-Martínez et al., 2012; Wang \& Han, 2009). The connection in parallel results in an overall current equal to the sum of the current generated by the individual MFC, while the voltage is constant. An electrical connection in parallel decreases the internal resistance and is therefore preferred (OrtegaMartínez et al., 2012). Nonetheless, when higher voltages are required, a combination of both parallel and series electrical connection has been proposed to avoid the use of a low voltage electronic controller to harvest energy and store power in a re-chargeable battery or super-capacitor, which would reduce overall efficiency (Gajda et al., 2018).

The fluidic arrangement of the MFC units in stacks is also important (Aelterman et al., 2006; Winfield et al., 2011). Both individual and cascade feeding have been tested. Individual feeding ensures that each cell operates under the same conditions of fuel, while the cascade feeding optimises the fuel efficiency and, therefore enhances the COD removal rates (Ledezma et al., 2013; Monasterio et al., 2015).

In this context, we provide here a versatile mathematical model that by functionally integrating mass transport phenomena with fluid dynamics and (bio)electrochemical processes at the steady-state, becomes a useful guide that can influence the development of future MFC designs. The model is used to identify design features, such as electrodes configuration and hydraulics, that have major impacts on the performance (in terms of power output and COD removal ability) of two miniature MFCs, tested both as individual units and in stacks. These two devices are characterised by the same anodic and cathodic specific and projected area per unit of volume, however they differ from each other for geometry and volume of the anodic chamber, electrode spacing and flow pattern. The effect of the anode geometry on the velocity distribution and the influence of electrode spacing on $\mathrm{pH}$ gradients is investigated.

\section{Experimental}




\section{Materials}

All reagents used were of analytical grade and purchased from Sigma-Aldrich and Alfa Aesar. The Synthetic Wastewater (SWW) was prepared by dissolving in reverse osmosis purified water: $0.693 \mathrm{~g} \mathrm{~L}^{-1}$ of $\mathrm{NaHCO}_{3}, 0.463 \mathrm{~g} \mathrm{~L}^{-1}$ of $\left(\mathrm{NH}_{4}\right)_{2} \mathrm{SO}_{4}, 0.278 \mathrm{~g} \mathrm{~L}^{-1}$ of $\mathrm{KH}_{2} \mathrm{PO}_{4}$, $0.23 \mathrm{~g} \mathrm{~L}^{-1}$ of $\mathrm{MgCl}_{2} .6 \mathrm{H}_{2} \mathrm{O}, 0.313 \mathrm{~g} \mathrm{~L}^{-1}$ of $\mathrm{CaCl}_{2}$ and $0.018 \mathrm{~g} \mathrm{~L}^{-1}$ of $\left(\mathrm{NH}_{4}\right) \mathrm{Fe}\left(\mathrm{SO}_{4}\right)_{2}$. Sodium acetate was used as the carbon source at a concentration varied within the range $0.1-6 \mathrm{~g}$ $\mathrm{L}^{-1}$, as specified. The solution was autoclaved prior to be used. Polydimethylsiloxane (PDMS, Dow Corning Sylgard 184) was purchased from Ellsworth Adhesives (UK).

\section{Design of the MFC units}

Two air-cathode single-cell MFC configurations were considered, $\mathrm{MFC}_{\mathrm{Conf} .1}$ and MFC $_{\text {Conf.2 }}$ (Figure 1). Both MFCs consist of a single chamber made of a piece of PDMS sandwiched between two Perspex plates. The anodic geometric volume is $346 \mu \mathrm{L}$ for $\mathrm{MFC}_{\mathrm{Conf} .1}$ and $128 \mu \mathrm{L}$ for $\mathrm{MFC}_{\mathrm{Conf} .2}$. In $\mathrm{MFC}_{\mathrm{Conf} .1}$ the anodic chamber has a circular crosssectional area, with a diameter of $1.05 \mathrm{~cm}$ and a height of $0.4 \mathrm{~cm}$. In this device, the proton exchange membrane (Nafion ${ }^{\circledR}$ 117, Sigma Aldrich) is sandwiched between the anode and the cathode, thus leading to a set-up with minimal electrode spacing, which can be approximated to the membrane thickness $(0.2 \mathrm{~mm})$. The device is positioned upright and the SWW is fed from the bottom to the top. The anodic chamber of MFC $\mathrm{Conf}_{2}$ is instead rectangular $\left(0.4 \times 0.8 \times 0.4 \mathrm{~cm}^{3}\right)$, and has a geometry previously reported (Chouler et al., 2016). Here, the electrode spacing is equal to the height of the anodic chamber, $4 \mathrm{~mm}$. The device is operated horizontally and the SWW flows through the two sides of the channel.

In both MFC $_{\text {Conf.1 }}$ and MFC Conf.2, carbon felt $_{\text {(Sigracell }}{ }^{\circledR}$ GFA6EA, specific surface area $35.3 \mathrm{~m}^{2} \mathrm{~g}^{-1}$, areal weight $500 \mathrm{~g} \mathrm{~m}^{-2}$, porosity $95 \%$ and $30 \mu \mathrm{m}$ roughness) was used as the anode material, while carbon paper (type C2, Freudenberg Fuel Cell Products, $225 \mu \mathrm{m}$ thickness) was used as the cathode material. The cathode, activated with a layer of platinum at a concentration of $0.5 \mathrm{mg} \mathrm{cm}^{-2}$, was hot pressed to the Nafion ${ }^{\circledR} 117$ proton exchange membrane at a temperature of $105^{\circ} \mathrm{C}$ and pressure of 1 ton for $15 \mathrm{~min}$ (Mateo et al., 2015). Table 1 summarises the difference between the two MFC configurations studied.

Table 1. Characteristics of the two MFC devices investigated. 


\begin{tabular}{|l|l|l|l|l|}
\hline & $\begin{array}{l}\text { Volume of the } \\
\text { anodic chamber } \\
\mu \mathrm{L}\end{array}$ & $\begin{array}{l}\text { Geometry of the } \\
\text { anodic chamber }\end{array}$ & $\begin{array}{l}\text { Electrode } \\
\text { spacing } \\
\mathrm{mm}\end{array}$ & $\begin{array}{l}\text { Flow } \\
\text { pattern of } \\
\text { the feeding } \\
\text { solution }\end{array}$ \\
\hline MFC $_{\text {Conf.1 }}$ & 346 & cylindrical & 0.2 & upright \\
\hline MFC $_{\text {Conf.2 }}$ & 128 & rectangular & 4 & horizontal \\
\hline
\end{tabular}

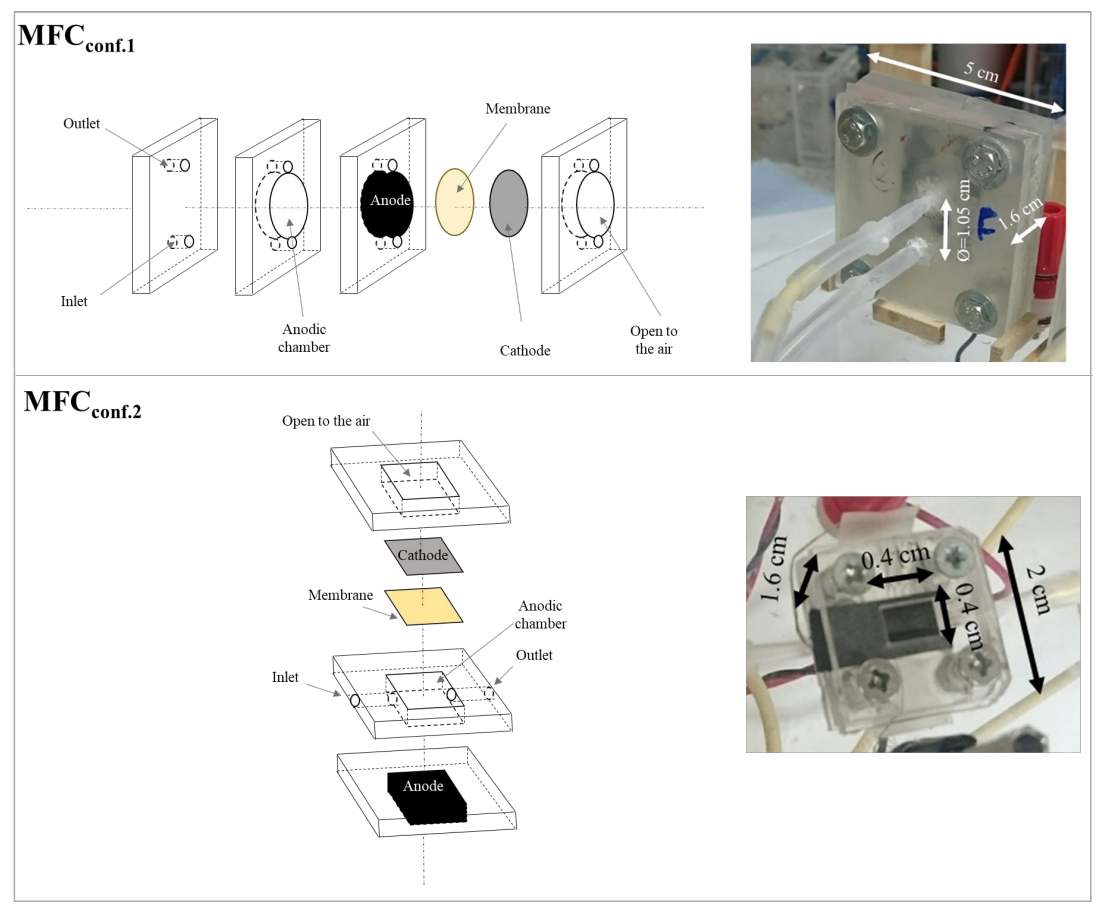

Figure 1. Schematic of $\mathrm{MFC}_{\mathrm{Conf} .1}$ and $\mathrm{MFC}_{\mathrm{Conf} .2}$ (not to scale) and actual photograph.

Operation of the MFCs units.

The MFCs were fed with SWW at a flow rate of $0.041 \mathrm{~mL} \mathrm{~s}^{-1}$ with a peristaltic pump (Ecoline, Ismatech, Germany), which led to a Hydraulic Retention Time (HRT) of $8.6 \mathrm{~s}$ in $\mathrm{MFC}_{\mathrm{Conf} .1}$ and $3.0 \mathrm{~s}$ in $\mathrm{MFC}_{\text {Conf.2. }}$. The MFCs were connected to a fixed external load to polarise the cell, and to an ADC-24 Pico data logger (Pico Technology, UK) to continuously monitor the output voltage. The enrichment of electroactive biofilm at the anode was performed by feeding the fuel cells with anaerobic sludge (Wessex Water, Scientific Laboratory in Saltford, UK), under continuous recirculation conditions for five days. During this time, $50 \%$ in volume of sludge in the feeding solution was replaced daily by fresh anaerobic sludge, taking into account a methodology that we have 
previously optimised (Vicari et al., 2017). From the sixth day, no more sludge was fed into the system and the feeding consisted of SWW only. The MFCs were kept under open circuit voltage (OCV) during the first two hours of operation. Afterwards, an external resistance $\left(R_{\text {ext }}\right)$ of $120 \Omega$ was applied. Once a steady voltage output was achieved (after approximately 10 days), $\mathrm{R}_{\text {ext }}$ was changed to match the internal resistance of the fuel cells, as previously suggested (Eimekawy et al., 2013).

Polarisation tests were performed with an Autolab PGSTAT128N (Metrohm, UK) on MFCs kept under OCV for two hours before the test. Ohm's law was used to calculate the output current $\left(E=I \times R_{\text {ext }}\right.$, where $E$ is the cell voltage and $I$ the output current), while Joule's law was used to calculate the power $\left(P=E^{2} / R_{\text {ext }}\right)$. The internal resistance, $R_{\text {int }}$, was calculated according to Equation 1:

$$
R_{\text {int }}=\frac{P_{\max }}{j_{\max }^{2}}
$$

where $\mathrm{j}_{\max }$ is the current density at the power peak $\left(\mathrm{P}_{\max }\right)$ (Chouler et al., 2016).

In this work, both current and power densities are referred to the geometric area of the anode $\left(0.86 \mathrm{~cm}^{2}\right.$ for $\mathrm{MFC}_{\mathrm{Conf} .1}$ and $0.32 \mathrm{~cm}^{2}$ for $\left.\mathrm{MFC}_{\mathrm{Conf.2}}\right)$.

The Chemical Oxygen Demand (COD) was measured according to the Environmental Protection Agency (EPA) method, using potassium dichromate as the oxidant. The samples to be analysed were previously filtered with a $0.2 \mu \mathrm{m}$ PTFE filter (Cole-Parmer), added to high range COD vials from Hannah, and incubated at $150^{\circ} \mathrm{C}$ for two hours. Once at room temperature, the absorbance of the resulting sample was measured with a HI83214 Hannah Multiparameter Photometer.

Due to the expected low conversion per pass, the COD removal data was obtained under batch recirculating conditions. Autoclaved SWW containing the target concentration of acetate was pumped from a $200 \mathrm{~mL}$ reservoir to the fuel cell and back, in a closed loop for a total of five hours. Care was taken to ensure that each test was performed by using clean tubing to reduce the risk of biofilm growth in the tubing. After five hours, samples were withdrawn from the reservoir and analysed and a new batch was set-up with fresh SWW.

Cascade and stacks of MFCs 
After being enriched individually, the MFCs were connected hydraulically in cascade, so that the outlet of one MFC would become the inlet of the following MFC. A cascade of up to four cells was built, over a total period of seven days, by adding a unit down the chain every two days, as shown Figure $1 \mathrm{~S}$ in the Supplementary Information. After seven days, two cascades were so obtained, one consisting of four MFC $_{\text {Conf.1 }}$ units and the other of four MFC $\mathrm{Conf}_{2}$ units.

Initially, the electrical performance of the single MFC units in the cascade was monitored, with individual electrical connection to the data logger. Afterwards, the MFCs in the cascade were electrically connected in parallel. Finally, two cascades of four MFCs were stacked together and electrically connected in parallel, leading to a stack of a total of eight MFCs for each MFC configuration tested (i.e. one for $\mathrm{MFC}_{\mathrm{Conf.1}}$ and one for $\mathrm{MF}_{\mathrm{Conf} .2)}$ ), as shown in Figure 1S.

\section{Results and discussion}

\section{Performance of the MFC units}

In this study, two miniature air-cathode microbial fuel cell configurations, $\mathrm{MFC}_{\mathrm{Conf} .1}$ and

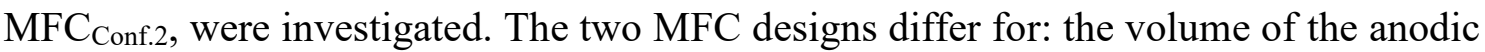
chamber; the geometry of the anodic chamber; the electrode spacing; and the flow pattern of the feeding solution.

The anode enrichment with electroactive biofilm in the MFCs was performed by following a procedure previously optimised, which involves five days of pre-incubation with activated sludge (Step 1), followed by feeding the anode with a COD of $2.5 \mathrm{gO}^{-\mathrm{dm}^{-}}$ ${ }^{3}$ and no bacteria (Step 2) (Vicari et al., 2017). Figure 2 reports the cell voltage versus time during Step 2. The typical three growth stages of the Monod kinetics can be observed. As shown, the apparent lag phase is shorter than a day $(0.8 \mathrm{~d})$, as a result of the five days of pre-incubation with sludge (Step 1). The steady-state phase is reached after approximately seven days of continuous feeding for $\mathrm{MFC}_{\mathrm{Conf} .1}$ and approximately five days for MFC $\mathrm{Conf}_{2 .}$.

The Gompertz model is a well-established and reliable method to describe the early stages of bacterial growth (Zwietering et al., 1990):

$$
N=A \cdot \exp \left(-\exp \left(\frac{\mu_{\max } \cdot e}{A} \cdot(\lambda-t)+1\right)\right)
$$


Where: $\mathrm{N}$ is the number of microorganisms present in the system; $\mathrm{A}$ is the maximum number of microoganisms achievable; $\lambda$ is the lag time; $e$ the Napier's constant; $\mu_{\max }$ is the maximum specific growth rate and $t$ is the time.

Equation 2 can only be used when substrate consumption is not a limiting factor, and it is therefore applicable to our system, considering that the MFCs were operated at saturating COD levels of $2.5 \mathrm{~g} \mathrm{O}_{2} \mathrm{dm}^{-3}$ (Zwietering et al., 1990).

Considering that during the enrichment stage the growth of electrogenic bacteria is directly related to the electricity production (Heidrich et al., 2016), and that, consequently, the limiting factor for electricity production during this stage stage is the bacterial growth, Equation 2 can be modified as follows:

$$
E=E_{\max } \cdot \exp \left(-\exp \left(\frac{\mu_{\max } \cdot e}{E_{\max }} \cdot(\lambda-t)+1\right)\right)
$$

Where: $\mathrm{E}_{\max }$ is the maximum voltage achievable under close circuit conditions; and $\mathrm{E}$ is the voltage at time $t$.

Equation 3 has been previously used to evaluate the growth of electroactive microorganisms in MFCs (Song et al., 2015), and successfully predict the increase of the cell voltage with time during the enrichment stage.

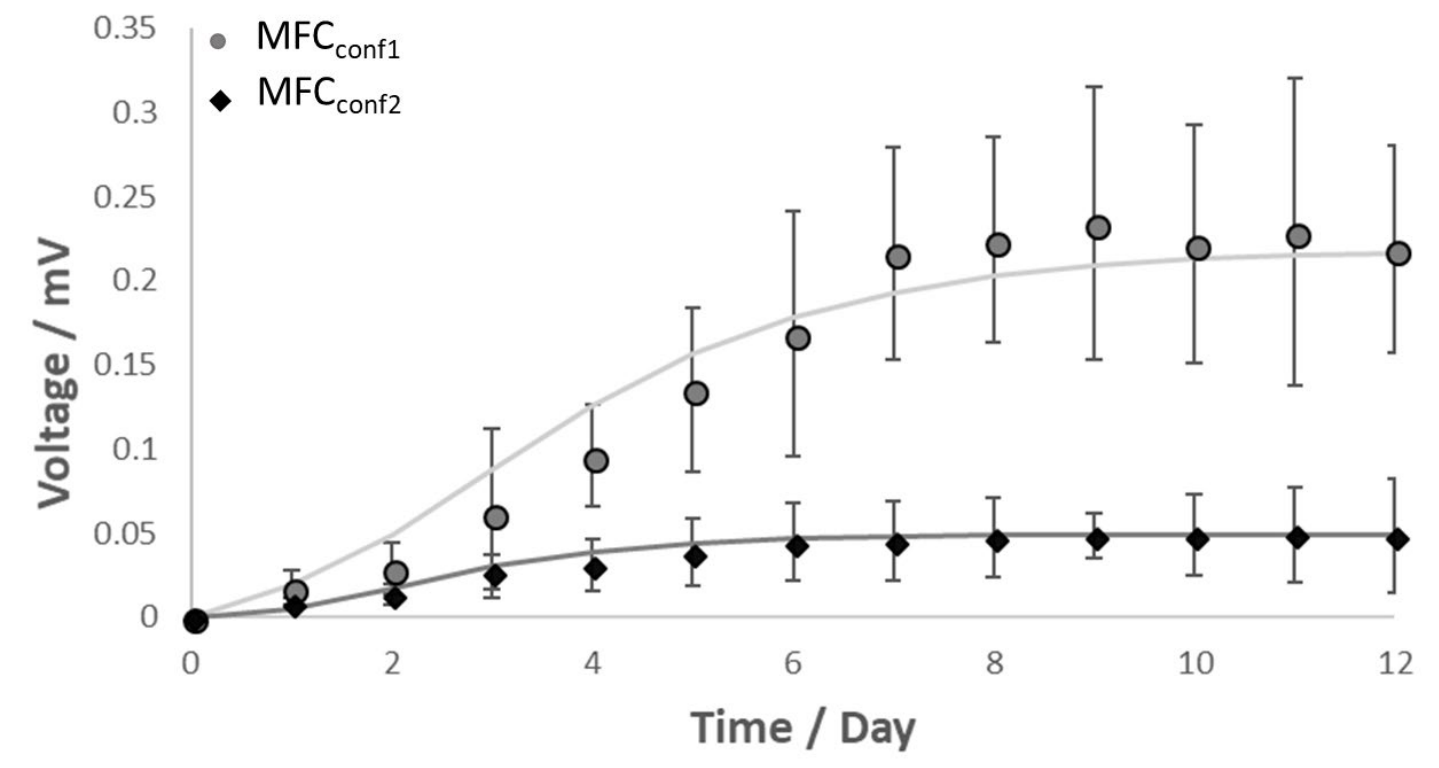

Figure 2. Output voltage generated by the two MFCs with time during Step 2 (i.e. after four initial days of incubation with anaerobic sludge). Data points refer to experimental data, while the curves were obtained from the Gompertz model. Each data point is the 
average of the output voltage per minute during a day. Error bars refer to five individual replicates.

In the case of $\mathrm{MFC}_{\mathrm{Conf} .1}$ a value of $\mu_{\max }$ of $0.04 \mathrm{~d}^{-1}$ was obtained, by taking into account the experimental values of $E_{\max }$ equal to $0.22 \pm 0.01 \mathrm{mV}$ at $120 \Omega$ and $\lambda$ of 0.8 day (Figure 2). For $\mathrm{MFC}_{\text {Conf.2, }}$, the $\mathrm{E}_{\max }$ of $0.045 \pm 0.001 \mathrm{mV}$ (lag phase time of 0.8 day) led to a $\mu_{\max }$ nearly three times smaller, $0.014 \mathrm{~d}^{-1}$. Higher growth rates have been reported for pure cultures, such as 3.2-0.96 d $\mathrm{d}^{-1}$ for Shewanella oneidensis (Zhang et al., 2014), 0.96-2.16 d ${ }^{1}$ for Geobacter sulfurreducens (Pinto et al., 2010), $0.34 \mathrm{~d}^{-1}$ Geobacter uraniireducens (Esteve-Núñez et al., 2005; Holmes et al., 2013), $<0.96 \mathrm{~d}^{-1}$ for Rhodoferax ferriducens and $1.68 \mathrm{~d}^{-1}$ for Clostridium butyricum (Patel \& Agnew, 1988; Risso et al., 2009). The low growth values obtained in this study might be a consequence of the use of the mixed anaerobic culture used to seed the MFCs, containing a low proportion of electroactive microorganism.

The current response to increasing organic load in the feed stream was subsequently tested. With this purpose, the MFCs were first starved for one day, thus leading to an output current almost null, and afterwards were fed with SWW with COD ranging from 0.1 to $5.5 \mathrm{gO}_{\mathrm{O}} \mathrm{dm}^{-3}$. Figure 3 reports the resulting current generated by the two MFC configurations. Both devices show similar trends up to COD of $2.5 \mathrm{~g}_{\mathrm{O} 2 \mathrm{dm}^{-3}}$, and have been interpolated with the Monod model (Trejos et al., 2009):

$\mu=\mu_{\max } \frac{C O D}{k_{S}+C O D}$

where $\mu_{\max }$ is the maximum specific growth rate.

Under these conditions, the value of $\mathrm{k}_{\mathrm{s}}$, obtained by fitting the Monod model was

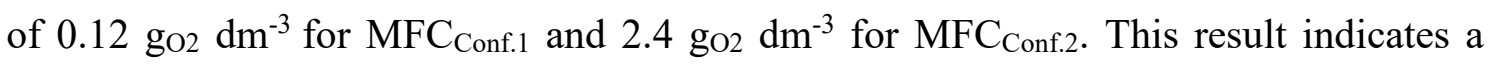
higher affinity for the substrate in the case of $\mathrm{MFC}_{\mathrm{Conf1}}$. One reason for this could be the different HRT in the two cells. During the start-up stage the slower HRT in MFC $\mathrm{Conf}_{1}$ (approximately three times slower than in $\mathrm{MFC}_{\text {Conf.2) }}$ might favour the development of slow-growing and more electrogenic microorganisms (Mateo et al., 2017). Overall, the HRTs in both fuel cells are very short compared to what reported in larger scale devices. Nonetheless, it has been previously shown that this does not affect the MFC performance (Walter et al., 2016a). 
For COD values larger than $2.5 \mathrm{gO}_{\mathrm{Odm}}^{-3}$, the trend of the output current is different in the two devices. In the case of $\mathrm{MFC}_{\mathrm{Confl}}$, the increase of current with COD is followed by a slow decrease. Considering that the current density is influenced by substrate consumption, and therefore by the grow rate of electrogenic bacteria at the anode, when COD in the inlet stream is higher than $2.5 \mathrm{go}_{\mathrm{O} 2} \mathrm{dm}^{-3}$ the behaviour of $\mathrm{MFC}_{\mathrm{Conf} 1}$ could be better interpreted with the Haldane model of substrate inhibition of bacterial growth (Jones et al., 1973):

$\mu=\mu_{\max } \frac{C O D}{k_{S}+C O D+\frac{C O D^{2}}{k_{I}}}$

Figure 3 compares the use of the two models to fit the experimental data obtained with MFC $_{\text {Confl. }}$ As shown, the Haldane model provides a better fit (maximum square error 0.01 $\mu \mathrm{A}$ ), with an inhibition constant, $\mathrm{k}_{\mathrm{I}}$, equal to $0.045 \mathrm{~g}_{\mathrm{O} 2} \mathrm{dm}^{-3}$.

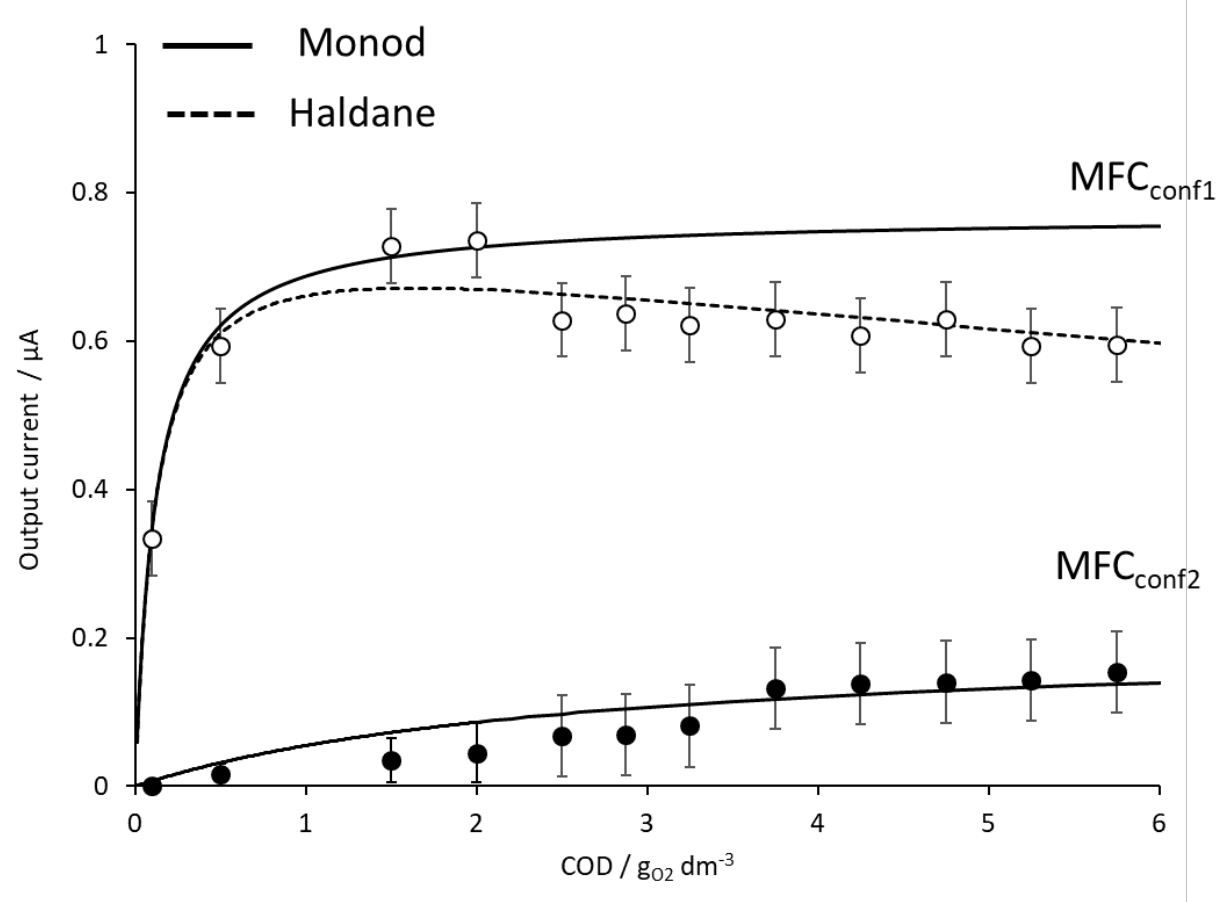

Figure 3. Current generated by the MFC devices fed with increasing COD values. Empty symbols: experimental data with $\mathrm{MFC}_{\mathrm{Confl}}$; full symbols: experimental data with $\mathrm{MFC}_{\mathrm{Conf2}}$. Error bars refer to five individual replicates. 
After 12 days of operation, a polarisation test was performed (see Figure $2 \mathrm{~S}$ and Figure $3 \mathrm{~S}$ in the Supplementary Information). The test revealed an optimal external resistance of $12 \mathrm{k} \Omega$ for $\mathrm{MFC}_{\mathrm{Conf} .1}$ and $69 \mathrm{k} \Omega$ for $\mathrm{MFC}_{\mathrm{Conf} .2}$. Under these conditions, the steady state current density was of $24.33 \pm 11.23 \mathrm{~mA} \mathrm{~m}^{-2}$ for $\mathrm{MFC}_{\mathrm{Conf} .1}$ and of $13.28 \pm$ $5.19 \mathrm{~A} \mathrm{~m}^{-2}$ for $\mathrm{MFC}_{\text {Conf.2. In }} \mathrm{MFC}_{\mathrm{Conf1}}$, the very short electrode spacing led to an internal resistance over five times smaller than the case of $\mathrm{MFC}_{\mathrm{Conf} .2}(12 \mathrm{~K} \Omega$ versus $69 \mathrm{~K} \Omega)$ and, consequently, to higher current generations (Fan et al., 2007; He et al., 2006; Jung et al., 2007; Song et al., 2009). The OCV was of $0.53 \pm 0.036 \mathrm{~V}$ for $\mathrm{MFC}_{\mathrm{Conf} .1}$, and of $0.45 \pm$ $0.023 \mathrm{~V}$ for $\mathrm{MFC}_{\mathrm{Conf} .2}$; the peak power density generated by $\mathrm{MFC}_{\mathrm{Conf} .1}$ was almost 1.3 times larger than the one generated by $\mathrm{MFC}_{\text {Conf. } 2}\left(0.061 \pm 0.013 \mathrm{~W} \mathrm{~m}^{-2}\right.$ versus $0.045 \pm$ $\left.0.007 \mathrm{~W} \mathrm{~m}^{-2}\right)$ and consequently, the current density was also higher $\left(0.334 \pm 0.044 \mathrm{~A} \mathrm{~m}^{-2}\right.$ versus $0.235 \pm 0.057 \mathrm{~A} \mathrm{~m}^{-2}$ ).

From the polarisation tests, both configurations show significant mass transfer limitations, which is typical in microbial fuel cells with three dimensional or porous anodes (Chouler et al., 2016). Since the same electrode material was used in the two configurations, the anodic/cathodic specific area and the projected area per unit of volume is the same in $\mathrm{MFC}_{\text {Conf.1 }}$ and $\mathrm{MFC}_{\text {Conf.2. As such, the difference in mass transfer }}$ limitations between the two configurations experimentally observed may be a consequence of the different velocity distribution in the two anodic chambers, leading to different concentration gradients. The different electrode spacing and arrangement in the two configurations may also lead to different $\mathrm{pH}$ gradients, which can influence the proton transport to the cathode and, consequently, the Oxygen Reduction Reaction (ORR) (Li et al, 2013).

To better understand this complex system, a simplified mathematical model in threedimension was developed for $\mathrm{MFC}_{\mathrm{Conf} .1}$ and $\mathrm{MFC}_{\mathrm{Conf} .2 \text {, which combines hydrodynamics, }}$ bioelectrochemical and electrochemical reactions, transport phenomena, and current distribution equations under steady-state operating conditions.

The model was based on the following assumptions.

1. The flow regime is assumed to be a steady flow of an incompressible fluid.

2. Acetate is the only carbon source, and the biofilm is under steady state conditions. 
3. The substrate consumption rate, $\mathrm{r}_{\mathrm{Ac}}\left(\mathrm{mol} \mathrm{m}^{-3} \mathrm{~s}^{-1}\right)$, follows the Nernst-Monod kinetics (Kato Marcus et al., 2007), which correlates the anode potential to the substrate concentration.

$$
r_{A c}=r_{\max } \frac{c_{A c}}{k_{S}+c_{A c}} \frac{1}{1+e^{-\frac{F}{R T} \eta_{A}}}
$$

Where $r_{\max }$ is the maximum specific rate of acetate consumption and $\eta_{\mathrm{A}}$ is the local overpotential at the anode, defined as the difference between the anode potential, $\mathrm{E}_{\mathrm{A}}$, and the potential $\mathrm{E}_{\mathrm{Ks}}$ observed when $\mathrm{c}_{\mathrm{A}}=\mathrm{k}_{\mathrm{s}}$ (Kato Marcus et al., 2007).

4. The biofilm is a conductor, and the electric conduction within the anode is limited by the biofilm conductivity only.

5. The kinetics of ORR at the cathode follows a Butler Volmer law, with mass transport limitations (Li et al., 2013)

$$
j_{C}=K c_{H^{+}} e^{-\frac{0.5 \eta_{C}}{R T}}
$$

Where $\eta_{C}(V)$ is the cathodic overpotential and $\mathrm{K}\left(5 \times 10^{-6} \mathrm{~A} \mathrm{~m}^{-1} \mathrm{~mol}^{-1}\right)$ (Li et al., 2013). Details on model equations and solution, and values of parameters are reported in Appendix A. Most of the parameters used are calculated from the experimental data obtained with the two MFC configurations tested. The diffusion coefficients were calculated with the well-known correlation of Wilke and Chang (Wilke \& Chang, 1955). A biofilm conductivity of $0.5 \mathrm{~S} \mathrm{~m}^{-1}$ has been used for modelling of electroactive microbial biofilms (Korth et al., 2015).

From the velocity distribution (Figure 4), it resulted that the difference in the feeding modality in the two MFC configurations has no marked influence on hydrodynamics. Since the velocities are very low, the flow regime is laminar in both cells. Both configurations present two dead zones and by-passes (preferential flows) near inlet and outlet ports. These zones are more remarkable in $\mathrm{MFC}_{\mathrm{Conf} .2}$. 

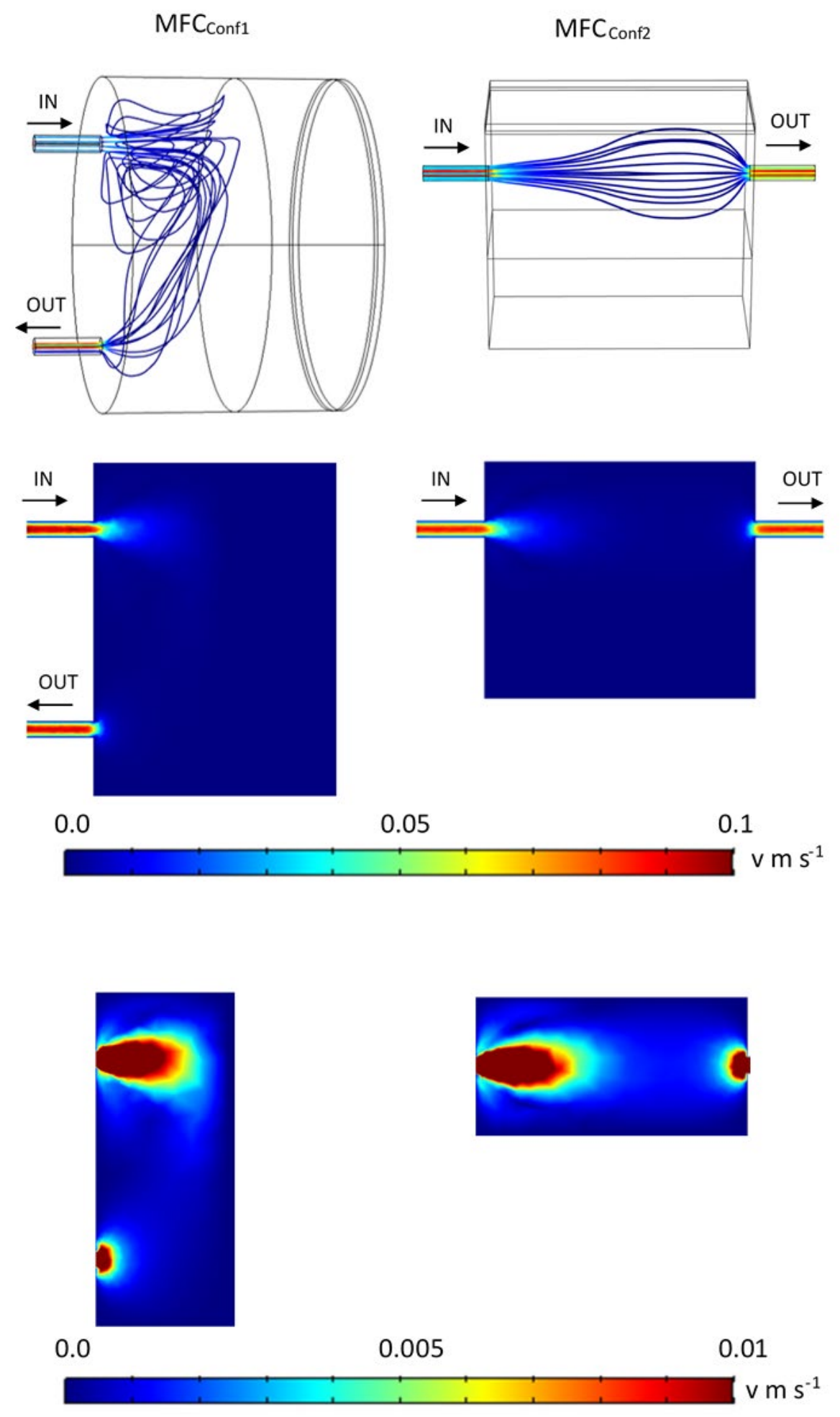

Figure 4. 3D streamlines and velocity profiles, with details of inlet and outlet, on the section planes shown in Figure 4S in the Supplementary Information. Feed flow rate 0.04 $\mathrm{cm}^{-3} \min ^{-1}$. a) velocity streamlines; b) velocity profile in the anodic cell, taking into account the electrode volume; c) magnification of the velocity profile in the anodic cell without taking into account the electrode. 
Figure 5 shows the COD profiles within the cells predicted by the model for three different values of inlet COD: $0.1 \mathrm{gO}_{\mathrm{Odm}} \mathrm{dm}^{-3} 0.5 \mathrm{gO}_{\mathrm{Odm}}^{-3}$, and $2.5 \mathrm{gO}_{\mathrm{O}} \mathrm{dm}^{-3}$. As shown, in both configurations most of the substrate consumption occurs within the porous anode. As such, the mass transfer limitations observed from the polarisation studies can be related mainly to the diffusion of acetate within the carbon felt. It results that when an inlet COD of $0.1 \mathrm{gO}_{\mathrm{O}} \mathrm{dm}^{-3}$ is used, a zone with low concentration can be observed in the cathodic zone corresponding to the inlet port. As such, the inlet COD used in the previous tests $\left(2.5 \mathrm{gO}_{\mathrm{O} 2 \mathrm{dm}^{-3}}\right)$ is indeed high enough to avoid local starvation in all the anodic chamber. A better exploitation of the anode volume is achieved with $\mathrm{MFC}_{\text {Conf.1, where }}$ the conversion per pass is higher. COD removal rate tests, performed by batch recirculating experiments, showed indeed a COD removal in $\mathrm{MFC}_{\mathrm{Conf} .1}$ approximately four times higher than the obtained with MFC Conf.2 $\left(330 \mathrm{~g}_{\mathrm{O} 2} \mathrm{dm}^{-3}\right.$ versus $84 \mathrm{go}_{\mathrm{O} 2 \mathrm{dm}^{-3} \text { over }}$ a period of five hours).

Our model, therefore, suggests that the cell design is the major cause for the difference in performance under steady state of the two MFC configurations. It also provides guidelines on both design and operation strategies to enhance performance. In $\mathrm{MFC}_{\mathrm{Conf} .1}$ for example, inlet ports with a wider diameter would lead to a better distribution of velocities and minimise by-passes. MFC $\mathrm{Conf}_{2}$ should be tested at higher HRTs, since the conversion of organic predicted by the model at the actual HRT is very low. 
A

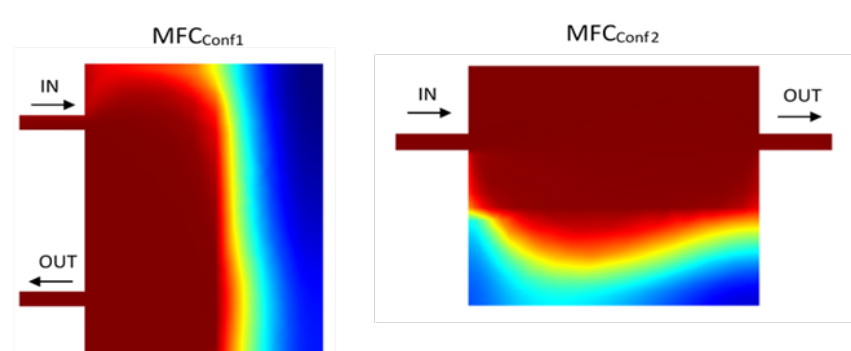

B
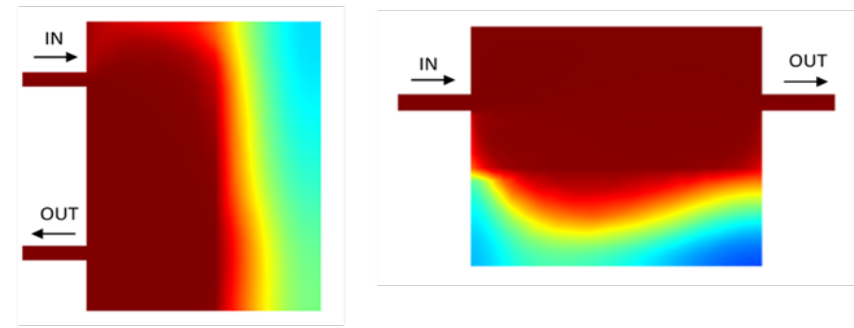

C

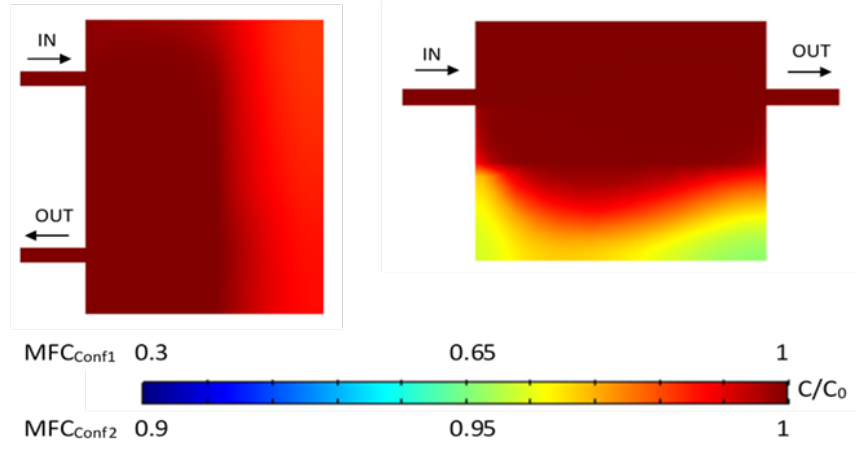

Figure 5: Simulated COD normalised profiles on the longitudinal section plane (shown in Figure 4S), for an inlet flow rate of $0.04 \mathrm{~cm}^{3} \mathrm{~s}^{-1}$ and inlet COD of $0.1 \mathrm{gO}_{\mathrm{O}} \mathrm{dm}^{-3}$ (A), 0.5 $\mathrm{g}_{\mathrm{O} 2} \mathrm{dm}^{-3}(\mathrm{~B})$, and $2.5 \mathrm{gO}_{\mathrm{O} \mathrm{dm}^{-3}}(\mathrm{C})$.

\section{Performance of the MFC stacks}

To improve the fuel efficiency, a cascade of up to four MFC units having the same configuration and hydraulically connected in series, was generated, as shown in Figure 1S. Regardless of the configuration, the sequential addition of an MFC unit down the cascade chain led to increasing COD removal efficiencies (Figure 6). The cascade configuration has been indeed already suggested as a strategic way to enhance COD removal (Ledezma et al., 2013; Monasterio et al., 2015). By fluidically connecting in series several MFCs, the available electrode size is effectively increased, without introducing depletion zones caused by diffusion boundary layers (Walter et al., 2016a). 
The COD removal by the MFC $\mathrm{Conf}_{2}$ cascade is approximately three times lower than the MFC $_{\text {Conf.1 }}$ cascade, in line with the performance observed by the individual unit and with the model predictions.

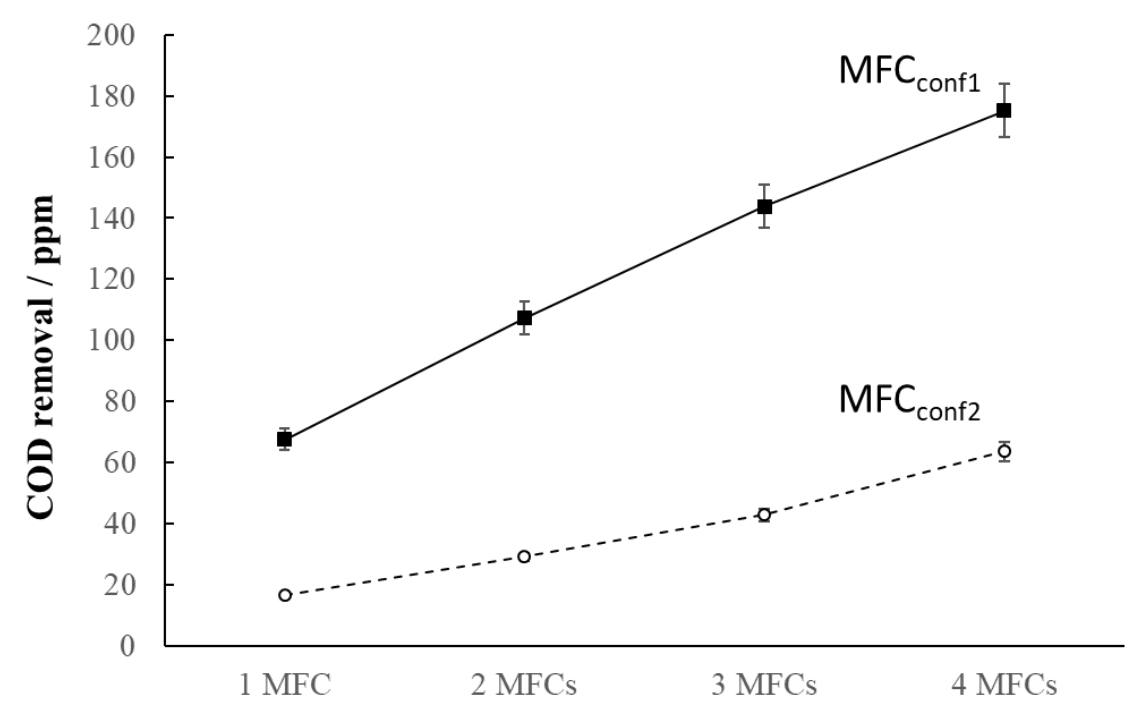

Number of MFCs in cascade

Figure 6. COD removal rates obtained after the sequential addition of MFC units in

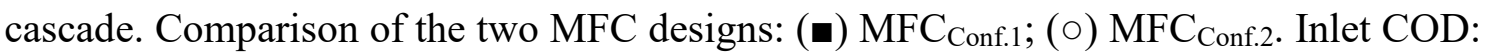
$4000 \mathrm{ppm}$. Each point refers to the removal obtained over a total of five hours of recirculating a SWW with the target COD starting value. Data is an average of two replicates.

To scale-up the power output, the MFC units in cascade were electrically connected in parallel (stack of one cascade). A stack consisting of two cascades of four MFC units each, for a total of eight devices, was also assembled (stack of two cascades). The choice for an electrical connection in parallel rather than in series was made on the basis of previous results, which shows internal resistance decreases for connections in parallel (Chouler et al., 2016).

Table 2 summarises the electrochemical performance of each stack and compares the two configurations used in this work. The power curves obtained in each case are reported in Figure 5S. For both configurations, the maximum current density increased up to six times when a stack of two cascades was tested. In particular, a current density of $2.1 \mathrm{~A} \mathrm{~m}^{-2}$ was 
obtained with a stack of eight $\mathrm{MFC}_{\mathrm{Conf} .1}$ units and $1.4 \mathrm{~A} \mathrm{~m}^{-2}$ was generated by a stack of eight $\mathrm{MFC}_{\mathrm{Conf} .2}$ cells. Similar trends were observed for the power output. This result is a consequence of the reduced internal resistance that is obtained with the stack. Also, the OCV of each stack is slightly higher than the OCV obtained with the single MFC unit. A similar behaviour has been previously reported for MFC stacks electrically connected in parallel (Ieropoulos et al., 2013).

Table 2. Electrochemical performance of the devices (individual and arranged in stack) studied in this work obtained from the polarisation tests (Figure 5S).

\begin{tabular}{c|ccccc} 
& Device & $\mathbf{j}_{\max }$ & $\mathbf{P}_{\max }$ & $\mathbf{R}_{\text {int }}$ & OCV \\
& & $\left(\mathbf{A ~ m}^{-2}\right)$ & $\left(\mathbf{m W} \mathbf{~ m}^{-2}\right)$ & $(\mathbf{k} \mathbf{\Omega})$ & $(\mathbf{V})$ \\
\hline \multirow{3}{*}{ MFC Conf.1 $^{*}$} & Single MFC & 0.334 & 61.23 & 12.14 & 0.434 \\
& Stack of 4 MFCs & 0.708 & 91.90 & 1.59 & 0.554 \\
& Stack of 8 MFCs & 2.081 & 301.55 & 0.5 & 0.594 \\
\hline \multirow{3}{*}{ MFCConf.2 $^{*}$} & Single MFC & 0.235 & 44.513 & 68.87 & 0.403 \\
& Stack of 4 MFCs & 0.338 & 83.65 & 11.08 & 0.522 \\
& Stack of 8 MFCs & 1.393 & 234.17 & 2.95 & 0.544 \\
\hline
\end{tabular}

As reported in Table 2, the internal resistance is reduced with the number of cells involved. The lowest internal resistance was in fact achieved with the stack of two cascades (eight devices), with values of $0.5 \mathrm{k} \Omega\left(\mathrm{MFC}_{\mathrm{Conf} .1}\right)$ and $2.9 \mathrm{k} \Omega\left(\mathrm{MFC}_{\mathrm{Conf} .2}\right)$. These results, in agreement with previous studies, is associated with an enhanced ion flow due to the functional increase in the anodic area achieved with stacking (Ortega-Martínez et al., 2012; Wang \& Han, 2009). When MFC units are electrically connected in parallel the internal resistance tends to the lowest (Papaharalabos et al., 2015). In addition, it has been demonstrated that this decrease in $\mathrm{R}_{\mathrm{int}}$ enhances the overall bioelectrochemical reaction rate, (Tharali et al., 2016).

\section{Conclusions}


The microbial fuel cell is an attractive carbon-neutral, sustainable and low-cost energy conversion technology that uses waste as a resource. To assist in the development of functional MFC designs, we have developed a versatile mathematical model, which was used to understand and predict the performance of two miniature MFC designs, as well as to relate any eventual difference to design factors.

By identifying the factors that influence the performance of two miniature MFCs, both as single units and in stack, this work will guide future functional designs for enhanced power outputs and wastewater treatments.

\section{Acknowledgements}

The authors thank: Wessex Water (UK) for providing anaerobic sludge; the Spanish Government for the Mobility Grant EST15/00016 to Sara Mateo and for financial support through the project CTQ2013-49748-Exp (Explora Program). 


\section{Appendix A}

\section{Mathematical model}

The fluid flow within the anodic chamber was modelled with the Navier-Stokes equations for incompressible fluids in free and porous media:

Free medium

$\rho_{W}(\boldsymbol{v} \nabla) \boldsymbol{v}=-\nabla P+\mu_{W} \nabla^{2} \boldsymbol{v}$

Porous medium (anode)

$\rho_{W}(\boldsymbol{v} \nabla) \boldsymbol{v}=-\nabla P+\mu_{W} \nabla^{2} \boldsymbol{v}+\frac{\mu_{W}}{k_{H E}} \varepsilon_{A} \boldsymbol{v}$

The boundary conditions for Equation 5 are: $v=0$ at the anodic chamber walls, fully developed laminar regime in the inlet nozzle, and atmospheric pressure at the outlet nozzle.

Transport and reaction of the $\mathrm{i}^{\text {th }}$ specie $\left(\right.$ Acetate, $\mathrm{H}^{+}$and $\left.\mathrm{OH}^{-}\right)$in free and porous media was modelled by:

$\nabla\left(D_{i} \nabla c_{i}\right)+v \nabla c_{i}=\sum_{j} \quad r_{i, j}$

Where $r_{i, j}$ is the $j^{\text {th }}$ reaction involving the $i^{\text {th }}$ specie. For Acetate $r_{i}$, are: substrate consumption (equation 3), and reactions of dissociation equilibrium; for $\mathrm{H}+$ are: reactions of dissociation and self-protonation of water equilibria; for $\mathrm{OH}$ - are the reactions of selfprotonation of water.

Equations A3 were solved with the boundary conditions:

$D_{i} \nabla c_{i}=0$

At the walls of the cell

$c_{i}=c_{i 0}$

At the inlet port, where $\mathrm{c}_{\mathrm{i} 0}$ is the feed concentration).

The diffusion coefficients in the porous anode $\left(\mathrm{D}_{\mathrm{i}, \mathrm{A}}\right)$ were obtained as:

$D_{i, A}=D_{i} \frac{\varepsilon_{F}}{\tau_{F}}$

The transport in the membrane was modelled by:

$\nabla\left(D_{i} \nabla c_{i}-u_{i} \nabla \mathrm{E}\right)=0$ 
Where

$u_{i}=D_{i} \frac{\gamma_{i} F}{R T}$

is the effective ionic mobility of the $i^{\text {th }}$ specie with charge $\gamma_{i}$

To obtain the potential distribution in the cell, the Ohm's law

$j_{E, S}=-\sigma_{E, S} \nabla V_{E, S}$

with conservation of current was solved in the electrodes (E) and in the electrolyte (S), with the relevant values of electrical conductivity.

The cathodic current density was expressed through Equation 6, the anodic one as $j_{A}=$ $\eta_{F} \frac{r_{A c}}{F z_{A c}}$ where $r_{A c}$ was obtained from Equation 5. The faradaic yield was obtained from batch recirculating experiments, as ratio between the charge measured and the theoretical charge for COD removal; $r_{\max }$ was adjusted to fit the experimental values of steady-state current.

Table A1 Parameters used in the mathematical model

\begin{tabular}{|c|c|c|}
\hline Symbol & Value [unit] & source \\
\hline$D_{A c}$ & $1.1 \times 10^{-9}\left[\mathrm{~m}^{2} \mathrm{~s}^{-1}\right]$ & \multirow{3}{*}{$\begin{array}{l}\text { (Korth } \\
\text { et al., 2015) }\end{array}$} \\
\hline $\mathrm{D}_{\mathrm{H}+}$ (electrolyte) & $9.3 \times 10^{-9}\left[\mathrm{~m}^{2} \mathrm{~s}^{-1}\right]$ & \\
\hline $\mathrm{D}_{\mathrm{OH}-}$ & $5.3 \times 10^{-9}\left[\mathrm{~m}^{2} \mathrm{~s}^{-1}\right]$ & \\
\hline $\mathrm{D}_{\mathrm{H}+}$ (membrane) & $5.3 \times 10^{-10}\left[\mathrm{~m}^{2} \mathrm{~s}^{-1}\right]$ & $\begin{array}{l}\text { (Harnis } \\
\text { ch et al., 2009) }\end{array}$ \\
\hline$\sigma_{\mathrm{E}}$ (anode) & $0.5\left[\mathrm{~S} \mathrm{~m}^{-1}\right]$ & $\begin{array}{l}\text { (Korth } \\
\text { et al., 2015) }\end{array}$ \\
\hline$r_{\text {MAX }}$ & $\begin{array}{l}0.002\left[\mathrm{~mol} \mathrm{~m}^{-3} \mathrm{~s}^{-1}\right](\operatorname{conf} 1) \\
0.001\left[\mathrm{~mol} \mathrm{~m} \mathrm{~s}^{-3} \mathrm{~s}^{-1}\right](\operatorname{conf} 1)\end{array}$ & \multirow{3}{*}{ This work } \\
\hline $\mathrm{k}_{\mathrm{s}}$ & $\begin{array}{l}1.87[\mathrm{mM}](\operatorname{conf} 1) \\
37.5[\mathrm{mM}](\operatorname{conf} 2)\end{array}$ & \\
\hline$\eta_{F}$ & $\begin{array}{l}4.310^{-4}(\operatorname{conf} 1) \\
3.410^{-4}(\operatorname{conf} 2)\end{array}$ & \\
\hline
\end{tabular}

The values of parameters are summarised in table A1. The numerical model was built and solved with the COMSOL Multiphysics ${ }^{\circledR}$ software: details of cell geometry and integration domains are reported in the Supplementary Data. 


\section{References}

Aelterman, P., Rabaey, K., Pham, H.T., Boon, N., Verstraete, W. 2006. Continuous electricity generation at high voltages and currents using stacked microbial fuel cells. Environmental Science and Technology, 40(10), 3388-3394.

An, J., Sim, J., Feng, Y., Lee, H.-S. 2016. Understanding energy loss in parallelly connected microbial fuel cells: Non-Faradaic current. Bioresource Technology, 203, 280-286.

Ashrafi, O., Yerushalmi, L., Haghighat, F. 2014. Greenhouse gas emission and energy consumption in wastewater treatment plants: impact of operating parameters. CLEANSoil, Air, Water, 42(3), 207-220.

Chouler, J., Padgett, G.A., Cameron, P.J., Preuss, K., Titirici, M.M., leropoulos, I., Di Lorenzo, M. 2016. Towards effective small scale microbial fuel cells for energy generation from urine. Electrochimica Acta, 192, 89-98.

Cimochowicz-Rybicka, M. Minimization of sewage sludge production-European trends and selected technologies. 2012. pp. 99-107.

Eimekawy, A., Hegab, H.M., Dominguez-Benetton, X., Pant, D. 2013. Internal resistance of microfluidic microbial fuel cell: Challenges and potential opportunities. Bioresour Technol, 142.

Esteve-Núñez, A., Rothermich, M., Sharma, M., Lovley, D. 2005. Growth of Geobacter sulfurreducens under nutrient-limiting conditions in continuous culture. Environmental Microbiology, 7(5), 641-648.

Fan, Y., Hu, H., Liu, H. 2007. Enhanced Coulombic efficiency and power density of air-cathode microbial fuel cells with an improved cell configuration. Journal of Power Sources, 171(2), 348-354.

Fernández de Dios, M.Á., del Campo, A.G., Fernández, F.J., Rodrigo, M., Pazos, M., Sanromán, M.Á. 2013. Bacterial-fungal interactions enhance power generation in microbial fuel cells and drive dye decolourisation by an ex situ and in situ electro-Fenton process. Bioresource Technology, 148, 39-46.

Gajda, I., Greenman, J., leropoulos, I.A. 2018. Recent advancements in real-world microbial fuel cells applications. Current Opinion in Electrochemistry.

Harnisch, F., Warmbier, R., Schneider, R., Schröder, U. 2009. Modeling the ion transfer and polarization of ion exchange membranes in bioelectrochemical systems. Bioelectrochemistry, 75(2), 136-141.

He, Z., Wagner, N., Minteer, S.D., Angenent, L.T. 2006. An upflow microbial fuel cell with an interior cathode: Assessment of the internal resistance by impedance spectroscopy. Environmental Science and Technology, 40(17), 5212-5217.

Heidrich, E.S., Curtis, T.P., Woodcock, S., Dolfing, J. 2016. Quantification of effective exoelectrogens by most probable number (MPN) in a microbial fuel cell. Bioresource Technology, 218, 27-30.

Holmes, D.E., Giloteaux, L., Barlett, M., Chavan, M.A., Smith, J.A., Williams, K.H., Wilkins, M., Long, P., Lovley, D.R. 2013. Molecular analysis of the In situ growth rates of subsurface geobacter species. Applied and Environmental Microbiology, 79(5), 1646-1653.

leropoulos, I.A., Greenman, J., Melhuish, C. 2013. Miniature microbial fuel cells and stacks for urine utilisation. International Journal of Hydrogen Energy, 38(1), 492-496.

Jones, G.L., Jansen, F., McKay, A.J. 1973. Substrate inhibition of the growth of bacterium NCIB 8250 by phenol. Microbiology, 74(1), 139-148.

Jung, R.K., Cheng, S., Oh, S.E., Logan, B.E. 2007. Power generation using different cation, anion, and ultrafiltration membranes in microbial fuel cells. Environmental Science and Technology, 41(3), 1004-1009. 
Kato Marcus, A., Torres, C.I., Rittmann, B.E. 2007. Conduction-based modeling of the biofilm anode of a microbial fuel cell. Biotechnology and Bioengineering, 98(6), 1171-1182.

Korth, B., Rosa, L.F.M., Harnisch, F., Picioreanu, C. 2015. A framework for modeling electroactive microbial biofilms performing direct electron transfer. Bioelectrochemistry, 106, 194206.

Ledezma, P., Greenman, J., leropoulos, I. 2013. MFC-cascade stacks maximise COD reduction and avoid voltage reversal under adverse conditions. Bioresource Technology, 134, 158165.

Li, M., Zhou, M., Tian, X., Tan, C., McDaniel, C.T., Hassett, D.J., Gu, T. 2018. Microbial fuel cell (MFC) power performance improvement through enhanced microbial electrogenicity. Biotechnology Advances, 36(4), 1316-1327.

Li, M.F., Liao, L.W., Yuan, D.F., Mei, D., Chen, Y.-X. 2013. pH effect on oxygen reduction reaction at Pt $\left(\begin{array}{lll}1 & 1 & 1\end{array}\right)$ electrode. Electrochimica Acta, 110, 780-789.

Mateo, S., D'Angelo, A., Scialdone, O., Cañizares, P., Rodrigo, M.A., Fernandez-Morales, F.J. 2017. The influence of sludge retention time on mixed culture microbial fuel cell startups. Biochemical Engineering Journal, 123, 38-44.

Mateo, S., Rodrigo, M., Fonseca, L.P., Cañizares, P., Fernandez-Morales, F.J. 2015. Oxygen availability effect on the performance of air-breathing cathode microbial fuel cell. Biotechnology Progress, 31(4), 900-907.

Monasterio, S., Mascia, M., Di Lorenzo, M., Vacca, A., Palmas, S. 2015. A cascade of miniature microbial fuel cells coupled with an electrochemical reactor for energy harvesting. 6th European Fuel Cell Technology and Applications Conference - Piero Lunghi Conference, EFC 2015. ENEA. pp. 305-306.

Ortega-Martínez, A., Juárez-López, K., Solorza-Feria, O., Ponce-Noyola, M.T., Ríos-Leal, E., Rinderknecht-Seijas, N.F., Poggi-Varaldo, H.M. 2012. Parallel connection and sandwich electrodes lower the internal resistance in a microbial fuel cell. Journal of New Materials for Electrochemical Systems, 15(3), 187-194.

Papaharalabos, G., Greenman, J., Melhuish, C., leropoulos, I. 2015. A novel small scale Microbial Fuel Cell design for increased electricity generation and waste water treatment. International Journal of Hydrogen Energy, 40(11), 4263-4268.

Patel, G.B., Agnew, B.J. 1988. Growth and butyric acid production by Clostridium populeti. Archives of Microbiology, 150(3), 267-271.

Pinto, R.P., Srinivasan, B., Manuel, M.F., Tartakovsky, B. 2010. A two-population bioelectrochemical model of a microbial fuel cell. Bioresource Technology, 101(14), 52565265.

Rahimnejad, M., Adhami, A., Darvari, S., Zirepour, A., Oh, S.-E. 2015. Microbial fuel cell as new technology for bioelectricity generation: A review. Alexandria Engineering Journal, 54(3), 745-756.

Ringeisen, B.R., Henderson, E., Pietron, J.J., Little, B., Ray, R., Jones-Meehan, J. 2005. Aerobic power generation by a miniaturized microbial fuel cell. 230th ACS National Meeting, Washington, DC.

Ringeisen, B.R., Henderson, E., Wu, P.K., Pietron, J., Ray, R., Little, B., Biffinger, J.C., JonesMeehan, J.M. 2006. High power density from a miniature microbial fuel cell using Shewanella oneidensis DSP10. Environmental Science and Technology, 40(8), 26292634.

Risso, C., Sun, J., Zhuang, K., Mahadevan, R., DeBoy, R., Ismail, W., Shrivastava, S., Huot, H., Kothari, S., Daugherty, S., Bui, O., Schilling, C.H., Lovley, D.R., Methé, B.A. 2009. Genome-scale comparison and constraint-based metabolic reconstruction of the facultative anaerobic Fe(III)-reducer Rhodoferax ferrireducens. BMC Genomics, 10, 447.

Santoro, C., Arbizzani, C., Erable, B., leropoulos, I. 2017. Microbial fuel cells: From fundamentals to applications. A review. Journal of Power Sources, 356, 225-244.

Song, T., Xu, Y., Ye, Y., Chen, Y., Shen, S. 2009. Electricity generation from terephthalic acid using a microbial fuel cell. Journal of Chemical Technology and Biotechnology, 84(3), 356-360. 
Song, Y.-C., Kim, D.-S., Woo, J.-H., Subha, B., Jang, S.-H., Sivakumar, S. 2015. Effect of surface modification of anode with surfactant on the performance of microbial fuel cell. International Journal of Energy Research, 39(6), 860-868.

Tharali, A.D., Sain, N., Osborne, W.J. 2016. Microbial fuel cells in bioelectricity production. Frontiers in Life Science, 9(4), 252-266.

Trejos, V.M., Alzate, J.F., Garcia, M.Á.G. 2009. Descripción matemática y análisis de estabilidad de procesos fermentativos. Dyna, 76(158), 111-121.

Vicari, F., Mateo, S., Fernandez-Morales, F.J., Cañizares, P., Galia, A., Scialdone, O., Rodrigo, M.A. 2017. Influence of the methodology of inoculation in the performance of air-breathing microbial fuel cells. Journal of Electroanalytical Chemistry, 803, 81-88.

Walter, X.A., Forbes, S., Greenman, J., leropoulos, I.A. 2016a. From single MFC to cascade configuration: The relationship between size, hydraulic retention time and power density. Sustainable Energy Technologies and Assessments, 14, 74-79.

Walter, X.A., Gajda, I., Forbes, S., Winfield, J., Greenman, J., leropoulos, I. 2016b. Scaling-up of a novel, simplified MFC stack based on a self-stratifying urine column. Biotechnology for Biofuels, 9(1).

Wang, B., Han, J.-I. 2009. A single chamber stackable microbial fuel cell with air cathode. Biotechnology Letters, 31(3), 387-393.

Wilke, C.R., Chang, P. 1955. Correlation of diffusion coefficients in dilute solutions. AlChE Journal, 1(2), 264-270.

Winfield, J., leropoulos, I., Greenman, J., Dennis, J. 2011. Investigating the effects of fluidic connection between microbial fuel cells. Bioprocess and Biosystems Engineering, 34(4), 477-484.

Yang, Y., Ye, D., Li, J., Zhu, X., Liao, Q., Zhang, B. 2016. Microfluidic microbial fuel cells: from membrane to membrane free. Journal of Power Sources, 324, 113-125.

Zhang, Y., Ng, C.K., Cohen, Y., Cao, B. 2014. Cell growth and protein expression of Shewanella oneidensis in biofilms and hydrogel-entrapped cultures. Molecular BioSystems, 10(5), 1035-1042.

Zwietering, M.H., Jongenburger, I., Rombouts, F.M., Van't Riet, K. 1990. Modeling of the bacterial growth curve. Applied and environmental microbiology, 56(6), 1875-1881. 